\title{
$\underline{\mathrm{O} J \mathrm{ED}}$
}

Volume 4, Issue 1 (2020), pp. 30-34

International Journal of

Entrepreneurship and Economic Issues

ISSN: 2616-0048 Print/ ISSN: 2631-231X Online

\section{Teacher Education: An Adaptive Response to the Movement to Online Instruction}

\author{
Robert Ceglie \\ Queens University of Charlotte, USA
}

\begin{abstract}
The COVID-19 pandemic has an impact on teacher training programs, as the shift to online instruction sent shock waves through the K-12 public education system in the United States. Teacher education programs were found in situations where their current student teachers needed significant additional support to navigate the rapid changes in the means that instruction was provided in their schools. This essay provides some insight on how one university navigated this process and provides suggestions for training future teachers.
\end{abstract}

Keywords: Covid-19, online instruction, pre-service teachers, teacher education

The COVID-19 pandemic influenced many different elements of our lives, but it may have an impact on how education is delivered in ways that may alter the future of teaching and learning in public schools across the world. In the United States, education quickly moved to online instruction with just under a half of the academic year of learning yet to occur. This led to major efforts by school district leaders to find solutions for the best method to continue educational delivery for their students. In addition, local colleges and universities with teacher preparation programs found themselves in a 
precarious position as they examined ways to support their student teachers who were currently in the field. Simultaneously, as college faculty were challenged with moving to online modalities, they sought out novel ways to support and mentor their students, conduct teaching evaluations, and complete teacher certification requirements. While nobody was prepared for this situation, often events such as this can afford opportunities to reflect on current practices and explore methods for improvement. This experience has provided a learning opportunity which will force colleges of education to evaluate ways to better support their pre-service teachers and in turn be better prepared for events like this in the future.

\section{CURRENT TEACHER EDUCATION PRACTICES}

The current landscape of teacher education prepares future teachers through a curriculum that requires coursework and clinical experiences in local schools and finally culminates in a semester long student teaching experience. The focus on much of the coursework is a blend between content and curriculum while the later portion of work is more focused on implementing curriculum. With respect to a preparation for online instruction, most colleges require some type of course in digital literacy. Queens University of Charlotte requires a digital literacy course which helps teachers utilize the current tools typically used in K-12 classrooms. We rely heavily on the International Society for Technology in Education (ISTE) standards for teachers (2017) which focus on seven elements of technology which teachers must be able to successfully navigate. In addition, these standards emphasize the need to empower learners and to aid in using technology as a learning catalyst. While a course in digital literacy is certainly important, it alone can't be a substitute for informing new teachers how to migrate their entire curriculum to an online format.

One advantage of the latest cadets of teachers is that they likely have had some of their own learning conducted in a virtual format. Estimates suggest that at least $30 \%$ of current college students have taken at least one course online (Black, 2020). Thus, it stands to reason that a percentage of these students will be future teachers. However, just taking an online course does not prepare someone for online instruction, but it does offer some insight into the student perspective of virtual learning. One particular challenge for student teachers is that they may not be familiar with the current Learning Management System (LMS) that their placement school is using. Few pre-service teachers would have utilized the same LMS or related technology that they are experiencing in their current placements, thus placing them at the start of a steep learning curve just to get started with 
online instruction. In addition, the local K-12 school district does not offer any type of technology training to support our incoming students. Thus, the pre-service teachers rely on their personal experience and those gleaned during their digital literacy coursework.

\section{COVID-19 IMPACT}

The local school district for Queens University of Charlotte's 12 student teachers were halfway into their semester-long student teaching experience when schools migrated to online instruction. At that point, all of our student teachers had assumed full responsibility for their classrooms and would typically continue this for at least five additional weeks. When schools moved online, they were serving as the primarily teacher and without appropriate technology or curriculum support, they faced considerable challenges during this transition. Overall, the move to online learning was chaotic and inconsistent as some teachers had no training or support for the school-level technology tools and yet they were expected to quickly learn technology such as Zoom and then were expected to deliver synchronous learning. Other teachers had leadership that attempted to provide training and guidance in the new technology and the school completed a slow migration to online instruction and did not force the use of any specific tool, including synchronous learning. Two specific students explained that their principal created benchmarks that all teachers had to meet before the school transitioned into any new stages of curriculum implementation. In addition, they felt there were ample support staff to assist in learning the new technologies. Those in this situation were able to spend more time modifying curriculum, creating engaging videos for their students, and felt better supported. As a supervisor to these students, I found it challenging to design the type of support needed because it varied so much.

Coupled with the frustration that the teachers felt as they tried to adapt to the new learning environment, they were also still being evaluated by faculty and school leadership. The state board of education failed to offer any guidance on how student teaching was to continue, nor did they provide guidance for if or how evaluations might change. My faculty continued our evaluation process, this time either evaluating synchronous lessons or evaluating asynchronous lessons created by our teachers. Perhaps the greatest challenge for our teachers was that most were afforded little technical support as they continued their teaching. As a consequence, college faculty began to ramp up our efforts to support their student's assigned to student teaching. We held more virtual seminars, prepared new material, designed short tutorials and brainstormed ways to support them. In 
many cases, we participated in the curriculum development and delivery process as a means to support our teachers. It is hard enough for novice teachers to student teach, but were now added additional challenges and demands of the new normal classroom. While all our teachers successfully completed their student teaching, we are fortunate, as other institutions did not fare as well.

\section{GOING FORWARD}

The experience that our student teachers faced moving to online instruction provided us with many lessons for changes that we can make going forward. The most logical suggestion is to embed additional technology instruction within our curriculum to support our teachers. Instead of just having our preservice teachers learn the technology, a new goal would be for them to create "real" online lessons using the technology that they know. We must embed more technology, better connect with the technology our districts use, and help our students design and implement online lessons prior to their student teaching experience. We must find opportunities for them to fully explore this and evaluate ways to improve as they move through our program. Second, this experience has reminded us to continue to remain flexible and sensitive to our student's needs, especially during challenging times. While our student teachers are usually highly stressed during this time, we found that the movement to a new learning platform really stretched their abilities to handle all their student teaching duties. We worked to offer additional one-on-one support and guidance, which appeared to really help support these students. Another important implication is that it is clear that it would be beneficial to reach out to our school partners and look at ways to: a) assist in training their teachers on technology as a way to learn exactly what they are using and need to know and, b) explore opportunities for our students to participate in their technology training prior to student teaching. Both of these ideas allow our students the ability to better understand what schools are using, how they are implementing their tools, and to potentially champion technology that the schools are currently not using. Our relationships with school leaders have been excellent; however, this experience helped us realize areas where we could extend ourselves to improve the experiences of both parties. Collectively, these recommendations would provide our pre-service teachers with additional preparation and support to be able to handle similar situations in the future. While the move to remote learning may not be the best situation for a child's learning, it is likely here to stay in some form or another. As we begin to prepare for the coming school year, many schools 
have already added some remote learning into their plans and having teachers prepared for this challenge will ensure better outcomes on future learning. Teachers of tomorrow will now be required teach in both face-toface and virtual environments and we must provide ample opportunities for our teachers to gain skill and confidence in these delivery methods.

\section{REFERENCES}

Black, G. C. (2020). Who are today's college students? Understanding the 21st century higher education digital learner. In Thornburg, A. W., Abernathy, D. F., \& Ceglie, R. J. (Eds.), Handbook of research on developing engaging online courses (pp. 1-13). IGI Global.

International Society for Technology in Education. (2017). ISTE national educational technology standards (NETS). International Society for Technology in Education.

ROBERT CEGLIE, PhD, is an Associate Professor of Education in the Cato School of Education at Queens University of Charlotte. His major research interested are focused on STEM learning, with a specific emphasis in science education and exploring means to extend opportunities for those traditionally marginalized by science. Email: ceglier@queens.edu 